\title{
PENGEMBANGAN MEDIA PEMBELAJARAN INTERAKTIF BERBASIS MODEL PROBLEM BASED LEARNING UNTUK MENINGKATKAN KEMAMPUAN BERPIKIR KREATIF FISIKA PESERTA DIDIK
}

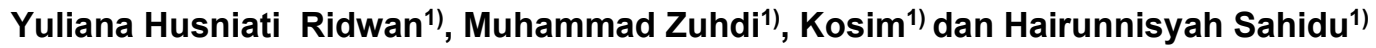 \\ 1)Program Studi Pendidikan Fisika, FKIP, Universitas Mataram, Mataram, NTB, Indonesia \\ Corresponding author : Yuliana Husniati \\ E-mail : yhusniati7@gmail.com
}

Diterima 08 Januari 2021, Direvisi 10 Februari 2021, Disetujui 13 Februari 2021

\begin{abstract}
ABSTRAK
Perkembangan ilmu pengetahuan dan teknologi semakin mendorong upaya-upaya pembaharuan dalam pemanfaatan hasil-hasil teknologi dalam meningkatkan kualitas pembelajaran. Pengembangan media yang dilakukan berupa pengembangan media pembelajaran interaktif berbasis model problem based learning. Tujuan penelitian ini yaitu menghasilkan media pembelajaran interaktif berbasis model problem based learning yang valid, efektif dan efisien untuk meningkatkan kemampuan berpikir kreatif fisika peserta didik. Metode penelitian yang digunakan yaitu $\mathrm{RnD}$ (Research and Development), dengan desain menggunakan model 4D. Pengumpulan data dilakukan dengan beberapa tahap diantaranya validasi ahli, uji coba terbatas dan angket respon peserta didik. Hasil penelitian menunjukkan bahwa media interaktif berbasis model problem based learning untuk meningkatkan kemampuan berpikir kreatif fisika peserta didik valid, efektif dan efisien digunakan dalam pembelajaran.
\end{abstract}

Kata kunci: media interaktif; problem based learning; kemampuan berpikir kreatif fisika

\begin{abstract}
The development of science and technology encourages refrom effort in the utilization of the results of technology in improving the quality of learning. Media development carried out in the form learning media development based on problem based learning models. The purpose of this study is to produce interactive learning media based on problem based learning models that are valid, effective and efficient to improve students' creative thinking skills in physics. The research method used is $\mathrm{RnD}$ (Research and Development), with design using the 4D model. Data collection was carried out in several stages including expert validation, limited trials and student questionnaires. The result showed tha interactive media based on problem based learning models to improve students' creative thinking skills in physics were valid, effective and efficient to use in learning.
\end{abstract}

Keywords: interactive media; problem based learning; creative thinking skills in physics

\section{PENDAHULUAN}

Perkembangan teknologi informasi dan komunikasi yang pesat telah memicu adanya perubahan sistem pembelajaran di sekolah. Pembelajaran konvensional yaitu metode pembelajaran yang banyak diterapkan di sekolah saat ini dinilai tidak menarik dan tidak relevan lagi bagi siswa karena pembelajaran konvensional masih menjadikan guru sebagai aktor utama dalam pembelajaran sehingga siswa tidak berperan secara aktif dalam membangun pengetahuan, sikap, dan perilaku. Hal yang paling penting dalam proses pembelajaran adalah terjadinya interaksi belajar antara guru dan siswa. Dari interaksi tersebut terjadi transfer knowledge antara keduanya. Penyampaian ilmu pengetahuan dapat disampaikan dalam berbagai model, metode, dan strategi pembelajaran terutama dalam pembelajaran fisika (Rohmani et al., 2015).

Fisika merupakan salah satu bagian dari sains yang mendasari perkembangan tekhnologi maju dan konsep hidup harmonis dengan alam. Pada tingkat SMA/MA fisika dipandang penting untuk diajarkan sebagai mata pelajaran tersendiri dengan beberapa pertimbangan. Pertama, pembahasan dan arahan pembelajaran fisika hendaknya didasarkan pada latihan pemecahan masalah untuk menumbuhkan kemampuan berpikir kreatif bukan pada penggunaan rumus-rumus fisika yang memiliki kecenderungan menggeser pembelajaran fisika menjadi pembelajaran matematika. Untuk menguasai konsep dan mengembangkan kemampuan berpikir kreatif, pembelajaran yang dilakukan haruslah bermakna. Pembelajaran bermakna 
(meaningful learning) menurut Harjono (2012) menganjurkan pentingnya pemahaman konsep-konsep dan hubungan antar konsep terutama dalam pembelajaran fisika yang merupakan salah satu cabang dari pembelajaran sains.

Pembelajaran lebih bermakna apabila peserta didik mampu memperoleh suatu pengetahuan secara utuh dengan menghubungkan konsep-konsep yang dipelajari, sehingga konsep yang diperoleh saat pembelajaran dapat diterima dengan baik dan tidak mudah dilupakan (Kosasih \& Sumarna, 2014) Kemampuan dalam menerima materi baru dan mengaitkan materi tersebut dengan pengetahuan yang telah ada pada struktur kognitif tentu akan memengaruhi kemampuan berpikir kreatif peserta didik. Munandar (2012) menyatakan bahwa kreatif adalah hasil interaksi individu dengan lingkungannya, kemampuan untuk membuat kombinasi baru, berdasarkan data, inoformasi, atau unsur-unsur yang sudah dikenal sebelumnya baik dilingkungan sekolah, keluarga, maupun dari lingkungan masyarakat. Kriteria penilaian kreatif berkaitan dengan aspek-aspek berpikir kreatif, yaitu 1) Fluency (berpikir lancar) 2) Flexibility (berpikir luwes) 3) Originality (orisinalitas berpikir) 4) Elaboration (penguraian).

Berdasarkan hasil observasi yang dilakukan peneliti di SMAN 1 Lingsar, didapatkan bahwa hasil belajar peserta didik kelas XI masih belum optimal. Pada proses pembelajaran fisika masih berpusat pada guru (teacher-center) dengan menerapkan metode ceramah. Penggunaan media pembelajaran yang dapat memudahkan guru dan peserta didik dalam menjelaskan serta memahami materi masih kurang dimanfaatkan. Guru lebih banyak menekankan pembelajaran yang memungkinkan peserta didik hanya mencatat, mendengarkan penjelasan dari guru dan mengerjakan soal sehingga kurang variatif. Akibatnya, peserta didik cenderung pasif di dalam proses pembelajaran. Peserta didik lebih tertarik apabila penggunaan media pembelajaran berupa video, gambar dan animasi selama proses pembelajaran, serta beberapa kali guru juga menggunakan power point dan video sebagai media pembelajaran (Rafmana et al., 2018). Untuk itu, diperlukan suatu pengembangan media pembelajaran interaktif yang dapat diterapkan dalam pembelajaran guna mengatasi rendahnya kemampuan berpikir kreatif fisika peserta didik. Salah satunya yaitu pengembangan media pembelajaran interaktif berbasis model PBL (problem based learning). Problem based learning merupakan pembelajaran yang menggunakan masalah dunia nyata sebagai suatu konteks bagi peserta didik untuk belajar tentang berpikir kreatif dan keterampilan pemecahan masalah, serta untuk memperoleh pengetahuan dan konsep yang esensi dari mata pelajaran (Elizabeth et al., 2018).

Dalam proses pembelajaran, teknologi seperti komputer adalah alat dalam multimedia dan jaringan web terluas di dunia yang sangat besar pengaruhnya terhadap peserta didik. Program multimedia interaksi merupakan salah satu media yang terdiri dari teks, grafik, foto, video, animasi dan musik. Karakteristik terpenting pada media pembelajaran interaktif adalah bahwa peserta didik tidak hanya memperhatikan penyajian atau objek, tetapi dipaksa untuk berinteraksi selama mengikuti pembelajaran Softwere yang digunakan peneliti untuk mengembangkan media pembelajaran interaktif adalah Articulate Storyline 3. Articulate Storyline 3 merupakan perangkat lunak yang menggabungkan teks, gambar, video, animasi dan suara sehingga dapat memberikan bentuk penyajian secara visual yang menarik. Materi yang dipilih peneliti adalah optika geometri yang terdapat pada KD 3.11 .

Media yang dikembangkan peneliti telah dilengkapi animasi dan video yang memberikan pengalaman langsung kepada peserta didik seperti layaknya sedang menyaksikan kejadian langsung di dalam kelas. Sejalan dengan penelitian (Skills, 2017) mengatakan bahwa pembelajaran problem based learning menggunakan multimedia lebih baik daripada menggunakan modul terhadap prestasi belajar peserta didik. Penelitian serupa juga pernah dilakukan oleh Wiyono (2015) pengembangan multimedia interaktif berbasis model problem based learning telah memenuhi kriteria valid, praktis dan memberikan dampak positif terhadap hasil belajar peserta didik.

Berdasarkan permasalahan di atas penelitian ini bertujuan untuk menghasilkan media pembelajaran interaktif berbasis model problem based learning yang valid, efektif dan efisien untuk digunakan sebagai media pembelajaran.

\section{METODE PENELITIAN}

Jenis penelitian yang digunakan adalah penelitian pengembangan atau Research and Development (R\&D) dengan 4D Models atau 4 tahapan utama menurut Sugiyono (2018), yaitu pendefinisian (Define), perancangan (Design), pengembangan (Develop) dan penyebarluasan (Disseminate) dengan subjek penelitian yaitu peserta didik SMAN 1 Lingsar Kelas XI MIA 3 tahun ajaran 2020/2021 yang terdiri dari 15 orang. Teknik 
pengumpulan data menggunakan lembar validasi skala likert 1-4 yang akan dinilai oleh 6 validator ahli yang terdiri dari tiga dosen dan tiga guru. Selanjutnya, dilakukan ujiccoba media interaktif dalam proses pembelajaran.

Analisis validitas media interaktif berbasis model problem based learning dicari dengan menggunakan persamaan

Keterangan:

$$
P=\frac{f}{N} \times 100 \%
$$

$f=$ skor yang didapat

$N=$ skor maksimal

$P=$ Harga persentase

Setelah mendapatkan hasil penilaian, dengan menggunakan tabel kecenderungan data untuk menentukan kategori penilaian. Kategori penilaian ada pada tabel 1 sebagai berikut.

Tabel 1. Kriteria Validitas Media dan Perangkat Pembelajaran

\begin{tabular}{cc} 
Kriteria & Persentase \\
\hline Sangat Valid & $80 \% \leq \mathrm{X}<100 \%$ \\
\hline Valid & $60 \% \leq \mathrm{X}<80 \%$ \\
\hline Cukup Valid & $40 \% \leq \mathrm{X}<60 \%$ \\
\hline Tidak Valid & $20 \% \leq \mathrm{X}<40 \%$ \\
\hline Sangat Tidak Valid & $0 \% \leq \mathrm{X}<20 \%$ \\
\hline
\end{tabular}
(Akbar, 2013)

Percentage Agreement (PA) yaitu persentase kesepakatan antar penilai yang merupakan suatu persentase kesesuaian nilai antara penilai pertama dengan penilai kedua. Percentage Agreement (PA) dapat dirumuskan:

$$
(\mathrm{PA})=\left(1-\frac{\mathrm{A}-\mathrm{B}}{\mathrm{A}+\mathrm{B}}\right) 100 \%
$$

Instrumen dikatakan reliabel jika nilai presentase kesepakatannya lebih atau sama dengan $75 \%$.

Peningkatan kemampuan berpikir kreatif fisika peserta didik dapat ditentukan dengan menggunakan Standar Gain. Standar Gain ditentukan dengan menggunakan persamaan berikut:

Keterangan:

$$
\text { Std }<g>=\frac{\bar{X}_{\text {sesudah }}-\bar{X}_{\text {sebelum }}}{\bar{X}_{\text {maks }}-\bar{X}_{\text {sebelum }}}
$$

$\bar{X}_{\text {sesudah }}=$ skor post-test

$\bar{X}_{\text {sebelum }}=$ skor pre-test

$\bar{X}_{\text {maks }}=$ skor maksimum 100

Berdasarkan hasil yang diperoleh dengan menggunakan standar gain, dikelompokkan kategori kemampuan berpikir kreatif fisika peserta didik berdasarkan Tabel 2 sebagai berikut.

Tabel 2. Interpretasi Standar Gain

\begin{tabular}{cc}
\hline Nilai $\langle\mathbf{g}\rangle$ & Klasifikasi \\
$0,70<g<1,00$ & Tinggi \\
\hline $0,30<g<0,70$ & Sedang \\
\hline
\end{tabular}

$0,0<\mathrm{g}<0,30 \quad$ Rendah

(Sundayana, 2015)

\section{HASIL DAN PEMBAHASAN}

Hasil penelitian dan pengembangan ini adalah produk berupa media pembelajaran interaktif dan perangkat pembelajaran pada materi optika geometri kelas XI SMA. Softwere yang digunakan untuk mengembangkan media interaktif ini adalah Articulate Storyline 3. Tahapan yang dilakukan pada penelitian dan pengembangan ini yaitu 1) Define (pendefinisian), 2) Design (perancangan), 3) Develop (pengembangan) dan 4) Disseminate (penyebarluasan).

\section{1) Define (pendefinisian)}

\section{a. Analisis awal}

Analisis awal bertujuan untuk menetapkan masalah dasar yang dihadapi oleh peserta didik. Analisis awal yang dilakukan peneliti bertempat di SMAN 1 Lingsar. Berdasarkan analisis awal menunjukan bahwa peserta cenderung tidak menyukai pelajaran fisika karena sulit dipahami dan banyak rumus-rumus, metode pelajaran yang monoton, kurangnya variasi/ penggunaan media pembelajaran.

\section{b. Analisis Tugas}

Analisis tugas adalah kumpulan prosedur untuk menentukan isi dalam suatu pembelajaran dengan merinci tugas isi materi ajar secara garis besar dari Kompotensi Inti (KI) dan Kompetensi Dasar (KD) sesuai dengan Kurikulum 2013. Pokok bahasan yang dikembangkan pada media interaktif adalah materi Optika Geometri.

c. Analisi Konsep

Pemilihan materi disesuaikan dengan kebutuhan guru dan peserta didik, serta indikator kompetensi yang diajarkan agar sesuai dan relevan. Analisis konsep merupakan identifikasi terhadap konsepkonsep penting yang diajarkan. Menyusun secara sistematis dan merinci konsep yang relevan serta mengaitkan satu konsep dengan konsep yang lain sehingga membentuk peta konsep. Peta konsep dapat dilihat pada gambar di bawah ini. 


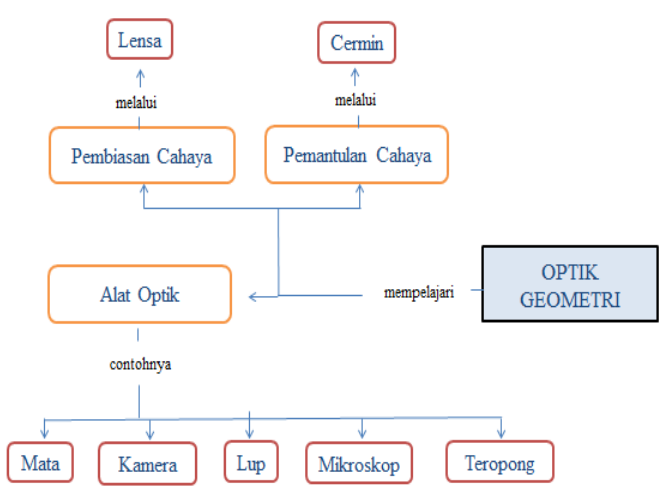

Gambar 1. Peta Konsep Optika Geometri

d. Spesifikasi Tujuan Pembelajaran Sebelum melakukan tahap perencanaan pembuatan media, perlu merumuskan tujuan dari indikator kompetensi yang akan digunakan sebagai acuan dalam pemilihan materi harus dirumuskan terlebih dahulu. Hal ini berguna untuk membatasi supaya tidak menyimpang dari tujuan semula pada saat membuat rancangan produk media.

\section{2) Design (perancangan)}

a. Penyusunan Perangkat Penelitian

Langkah ini dimulai dengan penyusunan instrumen pengumpulan data yaitu soal pre-test dan post-test. Soal yang disusun sebanyak empat soal dengan mengikuti indicator kemampuan berpikir kreatif. Setelah itu dilakukan penyusunan lembar validasi untuk dosen dan guru fisika serta angket respon peserta didik terhadap media interaktif.

\section{b. Pemilihan Media}

Media interaktif berbasis model problem based learning dipilih sesuai dengan kebutuhan peserta didik, setelah dilakukan wawancara dengan guru fisika. Menurut (Munadi, 2013) pemilihan media harus mempertimbangkan karakter peserta didik. Media interaktif mampu menarik perhatian peserta didik untuk belajar dan mengingat materi secara lebih mudah sehingga dapat meningkatkan kemampuan berpikir kreatif fisika peesrta didik.

\section{c. Pemilihan Format}

Format media interaktif disesuaikan dengan model tutorial. Model tutorial pada media interaktif merupakan salah satu jenis model pembelajaran yang memuat penjelasan, rumus, prinsip, began, tabel, definisi istilah dan latihan. Tutorial secara khusus terdiri dari diskusi mengenai konsep atau prosedur dengan bagian demi bagian atau kuis pada akhir akhir. Model tutorial bertujuan untuk menyampaikan atau menjelaskan materi tertentu, mengajukan pertanyaan dan memberikan umpan balik sesuai jawaban pengguna.

d. Desain Awal Media Interaktif Berbasis Model Problem Based Learning

Desain awal media pembelajaran di buat untuk membuat visualisasi media pembelajaran berdasarkan flowchart dan storyboard yang telah disusun peneliti. Berikut gambar hasil visualisasi media pembelajaran yang peneliti kembangkan.

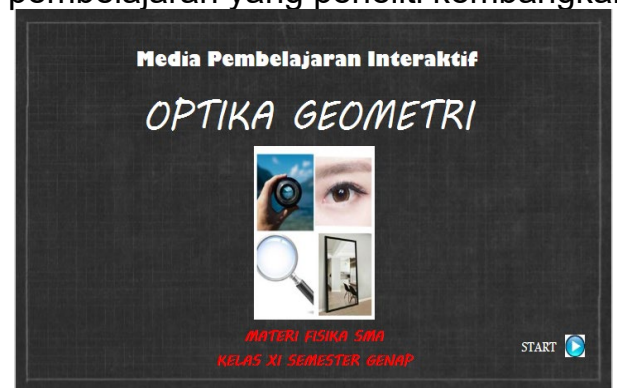

Gambar 2. Tampialan awal media interaktif

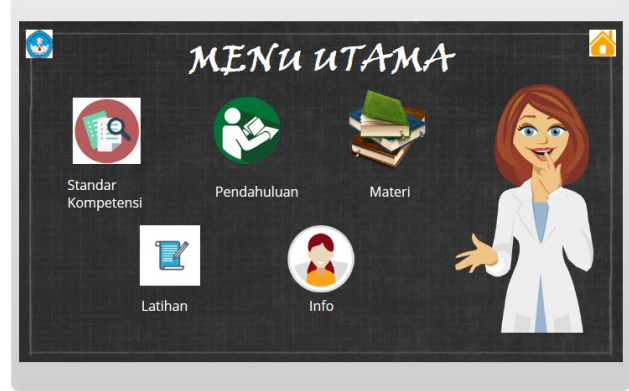

Gambar 3. Halaman menu utama

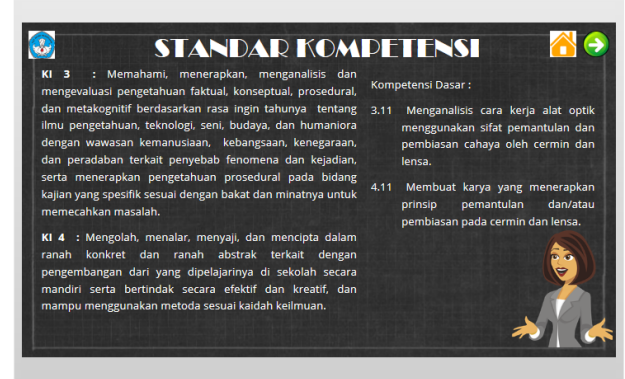

Gambar 4. Halaman standar kompetensi

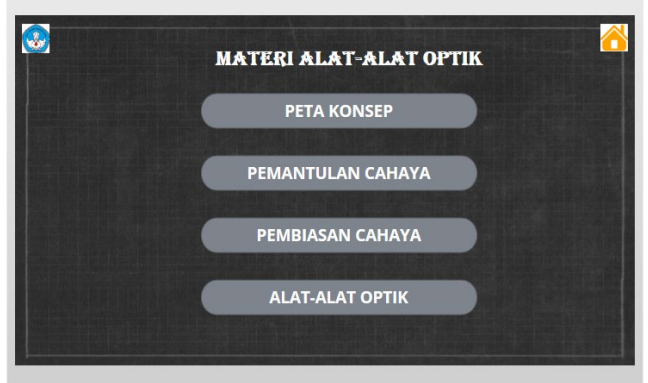

Gambar 5. Halaman menu materi 


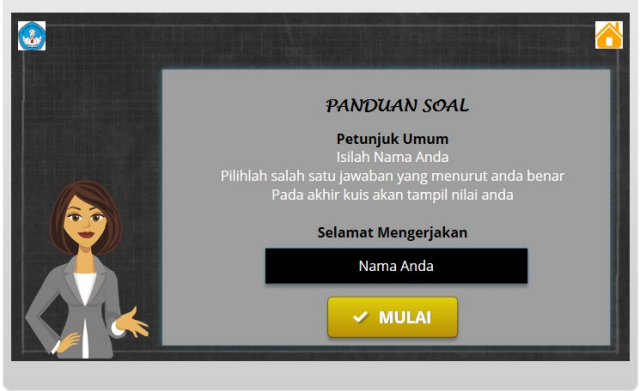

Gambar 6. Tampilan latihan soal

\section{3) Development (Pengembangan)}

Tahap pengembangan (develop) merupakan tahap untuk menghasilkan produk pengembangan yang dilakukan melalui dua langkah, yaitu uji validasi produk oleh validator ahli dan uji coba secara terbatas. Lembar validasi merupakan angket penilaian yang diisi oleh validator ahli (dosen dan guru fisika).

Untuk mengetahui validitas media pembelajaran dari aspek media dan materi. Hasil validator didapatkan dua data yaitu data kualitatif dan data kuantitatif. Berdasarkan data kualitatif peneliti diberikan saran, komentar dan masukan sebagai bahan revisi produk. Data kuantitatif penelitian ini diperoleh dari hasil penilaian validator ahli yang diberikan pada angket penilaian dengan skala penilaian 1 sampai dengan 4. Hasil penilaian dapat dilihat pada tabel 3 dan tabel 4 di bawah ini

Tabel 3. Hasil Validitas Media Interaktif dari Aspek Media

\begin{tabular}{clc} 
No & \multicolumn{1}{c}{ Aspek } & $\overline{\mathbf{X}}$ per Aspek \\
\hline 1 & Kualitas Media & $88 \%$ \\
\hline 2 & $\begin{array}{l}\text { Penggunaan } \\
\text { Bahasa }\end{array}$ & $84 \%$ \\
\hline 3 & Layout Media & $86 \%$ \\
\hline $\begin{array}{l}\text { Persentase (\%) } \\
\text { Kriteria }\end{array}$ & $\begin{array}{c}86 \% \\
\text { Sangat Valid }\end{array}$ \\
\hline
\end{tabular}

Tabel 4. Hasil Validitas Media Interaktif dari Aspek Media

$$
\text { No Aspek } \quad \overline{\mathrm{X}} \text { per Aspek }
$$

\begin{tabular}{clc}
\hline 1 & Kurikulum & $94 \%$ \\
\hline 2 & Penggunaan & $84 \%$ \\
\hline 3 & Pembukaan & $84 \%$ \\
\hline 4 & Penutup & $84 \%$ \\
\hline Persentase (\%) & $86,5 \%$ \\
\hline Kriteria & Sangat Valid \\
\hline
\end{tabular}

Berdasarkan penilaian validita media interaktif dari aspek media dan materi menggunakan angket validasi dari ahli (dosen dan guru fisika) maka dapat disimpulkan bahwa media interaktif valid untuk digunakan dengan kategori sangat valid.

Persentase kesepakatan antar penilai yang merupakan suatu persentase kesesuaian nilai antara penilai pertama dengan penilai lainnya. Reliabilitas perangkat dapat dilihat pada tabel 5 di bawah ini.

Tabel 5. Hasil Realibilitas Media Interaktif

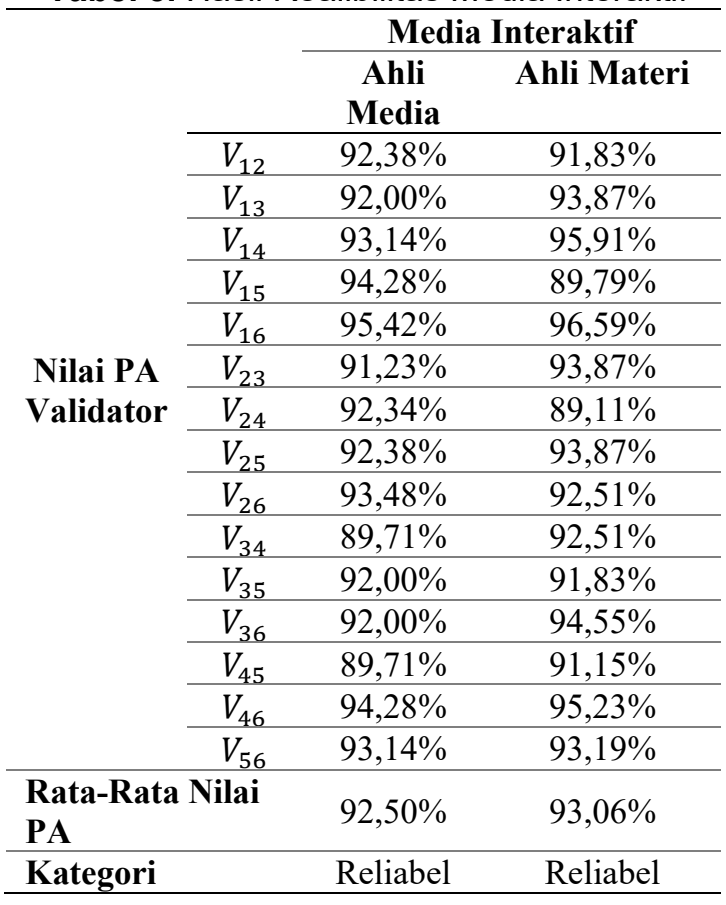

Berdasarkan tabel di atas media interaktif yang dikembangkan dapat dikatakan reliabel karena percentage agreement (PA) diatas $75 \%$.

Penilaian media interaktif dan perangkat pembelajaran dilakukan oleh validator ahli yang terdiri dari tiga dosen dan tiga guru mata pelajaran fisika melalui lembar validasi skala likert 1 sampai 4 .

Soal tes kemampuan berpikir kreatif berupa pre-test dan post-test yang digunakan untuk pengetahui peningkatan KBK peserta didik XI MIA 3 adalah sebanyak 4 butir soal. Hasil pre-test dan post-test ini didapatkan berdasarkan pembelajaran yang telah dilakukan secara terbatas dengan memanfaatkan media online di SMAN 1 Lingsar. Perolehan rata-rata $\mathrm{N}$-Gain untuk peserta didik kelas XI MIA 3 yang berjumlsh 15 orang adalah 0,60 dalam kategori sedang 
Tabel 6. Perolehan Rata-Rata KBK dengan uji $\mathrm{N}$-Gain

\begin{tabular}{ccc}
\hline $\bar{X}$ Pretest & $\bar{X}$ Posttest & N-Gain \\
\hline 50 & 80,67 & 0,60 \\
\hline
\end{tabular}

Tingkat efisiensi dalam kegiatan pembelajaran secara keseluruhan dari peserta didik terhadap produk ditentukan dengan butir pernyataan sebanyak 20 item. Hasil uji terbatas yang diperoleh pada 15 peserta didik sebagai pendukung hasil validasi dan uji $N$-Gain. Rekapitulasi data hasil respon terhadap media interaktif yang dilakukan oleh peserta didik menunjukkan bahwa peserta didik tertarik untuk menggunakan media interaktif selama proses pembelajaran.

\section{4) Disseminate (penyebarluasan)}

Tahap ini merupakan tahap produk atau perangkat yang telah dibuat akan disebarluaskan. Pada tahap ini peneliti menyebarkan hasil penelitian berupa artikel yang telah di submit pada e-journal.

\section{SIMPULAN}

Berdasarkan hasil penelitian dan pembahasan, maka dapat diambil kesimpulan bahwa media pembelajaran interaktif yang dikembangkan valid, efektif dan efisien untuk meningkatkan kemampuan berpikir kreatif fisika peserta didik.

\section{DAFTAR PUSTAKA}

Elizabeth, A., Sigahitong, M., Fisika, P. P., Nipa, U. N., \& No, J. K. (2018). Pengaruh Model Problem Based Learning Terhadap Kemampuan Berpikir Kreatif Peserta Didik SMA. Jurnal Pengkajian IImu dan Pembelajaran Matematika dan IPA IKIP Mataram, 6(2), 67-76.

Harjono, A. (2012). Perbedaan Strategi Pembelajaran Dan Pemberian Advance Organizer Pengaruhnya Terhadap Hasil Belajar Fisika Siswa Kelas X. Jurnal Pijar Mipa, 7(1), 13-17.

Kosasih, N., \& Sumarna, D. (2014). Pembelajaran Quantum dan Optimalisasi Kecerdasan. Bandung: Alfabeta.

Munandar, U. (2012). Pengembangan Kreativitas Anak Berbakat. Jakarta: Rineka Cipta.

Rafmana, H., Chotimah, U., \& Alfiandra. (2018). Pengembangan Multimedia Interaktif Berbasis Articulate Storyline Untuk Meningkatkan Motivasi Sma Srijaya Negara Palembang. Jurnal Bhinneka Tunggal Ika, 5(1), 52-65.

Rohmani, Sunarno, W., \& Sukarmin. (2015). Pengembangan Media Pembelajaran
Fisika Berbasis Multimedia Interaktif Terintegrasi Dengan Lks Pokok Bahasan Hukum Newton Tentang. Jurnal Inkuiri, $4(\mathrm{I}), 152-162$.

Sa'dun, A. (2013). Instrumen Perangkat Pembelajaran. Bandung: Remaja Rosdakarya Offset.

Skills, S. (2017). Pengembangan Multimedia Interaktif Bervisi SETS sebagai Alat Bantu Model Problem Based Learning (PBL) dalam Pembelajaran IPA di SMP untuk Meningkatkan Kemampuan Berpikir Kritis dan Keterampilan Sosial Peserta Didik. Pancasakti Science Education Journal. 2(2), 125-137.

Sugiyono. (2018). Metode Penelitian Pendidikan Pendekatan Kuantitatif Kualitatif dan R\&D. Bandung: Alfabeta.

Sundayana, R. (2015). Statistika Penelitian Pendidikan. Bandung: Alfabeta.

Wiyono, K. (2015). Pengembangan Multimedia Interaktif Berbasis Model Pembelajaran Problem Based Learning Pada Mata Pelajaran Fisika Pokok Bahasan Fluida Dinamis Untuk Sma Kelas XI. Jurnal Inovasi dan Pembelajaran Fisika. 2(1), 100-108.

Yuhdi, M. (2013). Media Pembelajaran. Jakarta: GP Press Group. 